\title{
Effect of Combined Administration of Dexamethasone and Captopril on Plasma Aldosterone Response to Angiotensin II in Normal Man
}

\author{
Kenji Mrzuno, M.D. and Soitsu Fukuchi, M.D.
}

\begin{abstract}
SUMmary
Aldosterone responses to angiotensin II were evaluated in normal subjects in 3 conditions, (1) with suppression of neither ACTH secretion nor angiotensin II, (2) with suppression of ACTH by dexamethasone, and (3) with suppression of both ACTH and angiotensin II by combined administration of dexamethasone and captopril. Baseline levels of plasma aldosterone were significantly lowered by administration of either dexamethasone or both dexamethasone and captopril. Aldosterone responsiveness to angiotensin-II was not altered by suppression of ACTH secretion. However, the responsiveness was significantly enhanced during suppression of both ACTH and angiotensin II. These results suggest that aldosterone response to angiotensin II in normal man is not dependent upon endogenous ACTH secretion, but to an action of angiotensin II on the pituitary gland to release ACTH. The combined administration of dexamethasone and captopril may be a useful maneuver to assess more precisely the reactivity of the adrenal cortex to angiotensin II in man.
\end{abstract}

\section{Additional Indexing Words:}

Aldosterone Angiotensin II ACTH Glucocorticoid Captopril

TT is widely recognized that the renin-angiotensin system is one of the major 1 regulators of aldosterone production in man. ${ }^{1,2)}$ On the other hand, there is evidence that angiotensin II has the potential to stimulate pituitary ACTH release. ${ }^{3,4)}$ The limited data from human studies are contradictory; whereas it has been reported that angiotensin $I I$ induces a brisk rise in plasma ACTH in normal man, ${ }^{5)}$ more recent documentation supports an inhibitory action of the octapeptide on ACTH release. ${ }^{6)}$ The question of whether angiotensin Japan.

From the Third Department of Internal Medicine, Fukushima Medical College, Fukushima,

Address for reprint: Kenji Mizuno, M.D., Third Department of Internal Medicine, Fukushima Medical College, 4-45 Sugitsuma-cho, Fukushima-shi 960, Japan.

Received for publication July 8, 1982. 
II acts to stimulate or suppress ACTH secretion may be of considerable importance, since even small fluctuations in plasma ACTH are known to be important in regulating at least short term plasma aldosterone levels in man. ${ }^{7,8)}$ Furthermore, the sensitivity of the adrenal cortex to angiotensin II may be influenced by endogenously circulating angiotensin II. ${ }^{9,10)}$ The present study was undertaken to determine 1) whether the aldosterone response to exogenous angiotensin II in normal man is dependent upon ACTH or an action of the octapeptide on the pituitary gland to release ACTH, and 2) whether the response is altered by simultaneous suppression of ACTH secretion and angiotensin II formation.

\section{Materials and Methods}

Five normal subjects, aged 24-36 yr, were studied. The subjects were given a diet containing $130-153 \mathrm{mEq}$ of sodium and $50-60 \mathrm{mEq}$ of potassium daily, for at least 7 days prior to the study. All urine was retained for measurements of 24-h excretion of sodium and potassium. Infusions of angiotensin II ( ${ }^{5} \mathrm{val}$-angiotensin II, Hypertensin, Ciba) were performed on 3 conditions in each subject, (1) with suppression of neither ACTH secretion nor angiotensin II (control), (2) with suppression of ACTH secretion by dexamethasone, and (3) with suppression of both ACTH and angiotensin II by simultaneous administration of dexamethasone and captopril. Both dexamethasone $(0.5 \mathrm{mg} / \mathrm{dose})$ and captopril $(25 \mathrm{mg} / \mathrm{dose})$ were given 4 times $(06: 00,12: 00,18: 00,24: 00)$, for 2 days before the infusion. On each day of infusion, the subjects remained supine in bed after fasting from 18:00 h on the previous evening. A venous line was inserted into each arm at $07: 30 \mathrm{~h}$, one for infusion and the other for blood sampling. At the completion of a 30-min infusion of $5 \%$ dextrose $(0.1 \mathrm{ml} / \mathrm{min})$, angiotensin II was infused incrementally at $0.2,0.4,0.8,1.0,1.2$, and $2.5 \mathrm{pM} / \mathrm{Kg} / \mathrm{min}$ for $15 \mathrm{~min}$ at each rate and $5.0 \mathrm{pM} / \mathrm{Kg} / \mathrm{min}$ was infused for $30 \mathrm{~min}$. Blood samples were drawn from the opposite arm at 15 and $30 \mathrm{~min}$ of dextrose administration and at the completion of each rate of angiotensin II infusion for measurements of concentrations of plasma aldosterone (PAC), cortisol, angiotensin II, and serum angiotensin-converting enzyme activity. The plasma samples were taken into iced tubes and immediately centrifuged at $4^{\circ} \mathrm{G}$, and the plasma or serum was stored at $-20^{\circ} \mathrm{C}$ prior to analysis. All determinations were performed within 7 days after sampling. Pulse rate and blood pressure (Arteriosonde, RaLoche Inc) readings were performed every 5 min during the dextrose and angiotensin II infusions. Radioimmunoassay methods were used for determination of $\mathrm{PAC}^{111}{ }^{11}$ cortisol, $^{12)}$ and angiotensin II. ${ }^{13)}$ Serum angiotensin- 
converting enzyme activity was measured by a spectrophotometric assay, using hippuryl-1-histidyl-1-leucine (Protein Research Foundation, Osaka, Japan) as the substrate. ${ }^{14)}$ One unit of the enzyme activity was defined as 1 nanomole hippuric acid $/ \mathrm{ml} / \mathrm{min}$ at $37^{\circ} \mathrm{C}$. Student's paired and unpaired sample t-tests were used for statistical analyses.

\section{RESULTS}

The equilibration of the standardized electrolyte intake was achieved by the fourth hospital day, as indicated by the urinary sodium and potassium excretion of $148.5 \pm 5.6$ (mean \pm S.D.) and $52.8 \pm 8.8 \mathrm{mEq} /$ day, respectively. Serum potassium and sodium were not altered by administration of either dexamethasone or dexamethasone plus captopril (Table I). The mean blood pressurc rose stepwise during angiotensin II infusion to a maximum of $12.1 \mathrm{mmHg}$ (systole) and $10.6 \mathrm{mmHg}$ (diastole) in the control condition. Neither dexamethasone nor dexamethasone plus captopril administration altered the overall blood pressure response to angiotensin II, as shown in Table II. Pulse rates did not change on each infusion day and did not change during angiotensin II administration.

Under control conditions, plasma cortisol fell from a baseline of $7.9 \pm$ 4.2 (mean \pm S.D.) to $6.8 \pm 1.3 \mu \mathrm{g} / 100 \mathrm{ml}$ by the completion of the highest dose of angiotensin II. After dexamethasone administration, plasma cortisol fell to $0.55 \pm 0.21 \mu \mathrm{g} / 100 \mathrm{ml}$, but did not change at the highest dose of angiotensin II. After dexamethasone plus captopril treatment, plasma cortisol also fell to $0.48 \pm 0.11 \mu \mathrm{g} / 100 \mathrm{ml}$, but did not change at the highest dose of angiotensin II. The preinfusion levels of plasma angiotensin II were $36.0 \pm 8.0 \mathrm{pg} / \mathrm{ml}$ in the control experiments and $33.0 \pm 10.0 \mathrm{pg} / \mathrm{ml}$ with dexamethasone. By contrast, plasma angiotensin II levels decreased considerably to $12.0 \pm 3.1 \mathrm{pg} / \mathrm{ml}$ ( $\mathrm{p}<0.001$, as compared with the control and dexamethasone administration)

Table I. Effects of Dexamethasone and Captopril on Plasma Concentration of Cortisol, Serum Potassium, Sodium, and Angiotensin-Converting Enzyme Activity

\begin{tabular}{l|c|c|c|c}
\hline & $\begin{array}{c}\text { Plasma cortisol } \\
(\mu \mathrm{g} / 100 \mathrm{ml})\end{array}$ & $\begin{array}{c}\text { Serum potassium } \\
(\mathrm{m} \mathrm{Eq} / \mathrm{L})\end{array}$ & $\begin{array}{c}\text { Serum sodium } \\
(\mathrm{mEq} / \mathrm{L})\end{array}$ & $\begin{array}{c}\text { Converting venzyme } \\
(\mathbf{U} / \mathrm{m})\end{array}$ \\
\hline Control & $7.9 \pm 4.2$ & $4.2 \pm 0.3$ & $140.5 \pm 1.5$ & $20.0 \pm 3.4$ \\
Dexamethasone & $0.55 \pm 0.21 * *$ & $4.4 \pm 0.2$ & $140.0 \pm 0.9$ & $15.8 \pm 8.6$ \\
$\begin{array}{c}\text { Dexamethasone } \\
\text { and Captopril }\end{array}$ & $0.48 \pm 0.11 * *$ & $4.1 \pm 0.1$ & $141.2 \pm 0.7$ & $4.1 \pm 2.2 * \dagger$
\end{tabular}

Each value is given as mean \pm S.D. Significance of differences: $* p<0.05$, as compared with the dexamethasone-treated group, $\dagger \mathrm{p}<0.001$, as compared with the control, ** $\mathrm{p}<0.001$, as compared with the control. 


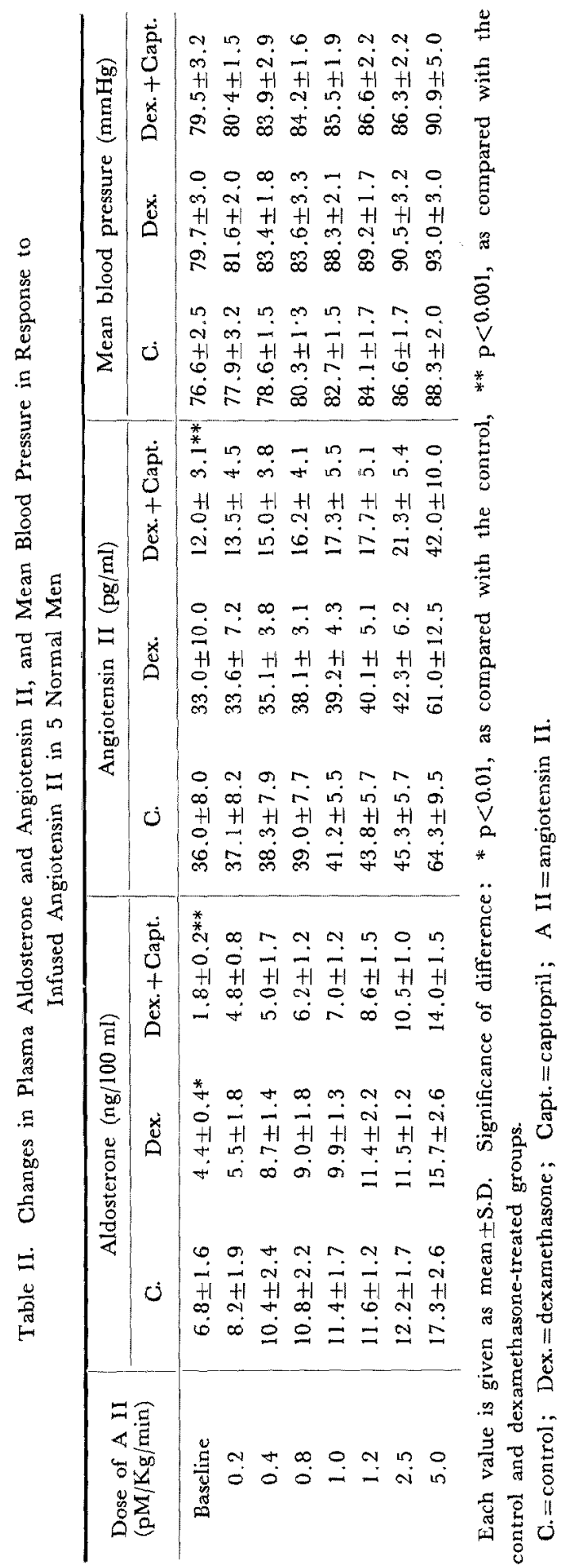




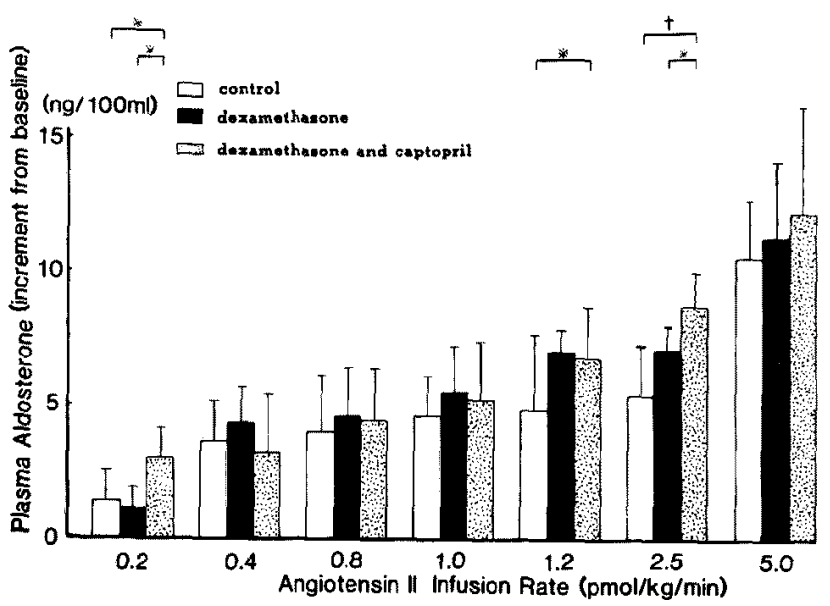

Fig. 1. Increments in plasma aldosterone levels with angiotensin II. Vertical lines indicate the standard deviation. ${ }^{*} \mathrm{p}<0.05, t_{\mathrm{p}}<0.01$.

with dexamethasone plus captopril administration (Table II). Plasma angiotensin II levels were incrcased stepwise by the incremental infusion of angiotensin II on each day (Table II). The control serum angiotensin-converting enzyme activity was $20.0 \pm 3.4$ units. It was $15.6 \pm 6.6$ units with dexamethasone administration, and it fell significantly to $4.1 \pm 2.2$ units with dexamethasone plus captopril ( $\mathrm{p}<0.001$, compared with the control; $\mathrm{p}<0.05$, compared with dexamethasone administration).

The preinfusion levels of PAC were lower in each subject after administration of either dexamethasone or both dexamethasone and captopril than the control value (control, $6.8 \pm 1.6 \mathrm{ng} / 100 \mathrm{ml}$ versus dexamethasone, $4.4 \pm$ $0.4 \mathrm{ng} / 100 \mathrm{ml}, \mathrm{p}<0.01$; control versus dexamethasone plus captopril, $1.8 \pm$ $0.2 \mathrm{ng} / 100 \mathrm{ml}, \mathrm{p}<0.001$ ) (Table II). The preinfusion levels of PAC after dexamethasone plus captopril administration were also significantly lower than those of the dexamethasone group. The aldosterone response to angiotensin II, measured by the change in PAC from baseline during angiotensin II infusion, was not altered by dexamethasone administration at any rate of angiotensin II infusion (Fig. 1). Conversely, in the group treated with dexamethasone plus captopril, the aldosterone responsiveness was significantly greater than in the control group at the $0.2(1.4 \pm 1.0 \mathrm{ng} / 100 \mathrm{ml}$ versus $3.1 \pm$ $0.9 \mathrm{ng} / 100 \mathrm{ml}, \mathrm{p}<0.05), 1.2(4.4 \pm 1.9 \mathrm{ng} / 100 \mathrm{ml}$ versus $6.9 \pm 1.2 \mathrm{ng} / 100 \mathrm{ml}$, $\mathrm{p}<0.05)$, and $2.5(5.4 \pm 1.2 \mathrm{ng} / 100 \mathrm{ml}$ versus $8.7 \pm 0.7 \mathrm{ng} / 100 \mathrm{ml}, \mathrm{p}<0.01)$ $\mathrm{pM} / \mathrm{Kg} / \mathrm{min}$ infusion rates. The change in $\mathrm{PAC}$ in response to angiotensin II infusion in the dexamethasone plus captopril group was also significantly greater than that in the group treated with dexamethasone at the $0.2(1.3 \pm$ $0.7 \mathrm{ng} / 100 \mathrm{ml}$ versus $3.1 \pm 0.9 \mathrm{ng} / 100 \mathrm{ml}, \mathrm{p}<0.05)$ and the $2.5(7.2 \pm 0.9 \mathrm{ng} /$ 
$100 \mathrm{ml}$ versus $8.7 \pm 0.7 \mathrm{ng} / 100 \mathrm{ml}, \mathrm{p}<0.05) \mathrm{pM} / \mathrm{Kg} / \mathrm{min}$ infusion rates.

\section{Discussion}

Based on experiments in dogs, angiotensin II has been classified as a corticotropin releasing hormone. ${ }^{3)}$ This is derived from the finding that infusions into the anterior pituitary or into the third ventricle can stimulate ACTH release. ${ }^{314)}$ In man, though, angiotensin-ACTH relationships are less clear. Rayyis et $a^{5)}$ observed that a pressor dose of angiotensin II in normal man increased immunoreactive ACTH levels and suppressed plasma cortisol levels. They concluded that angiotensin II acted on the adrenal gland to inhibit cortisol synthesis or release, and that the increase in ACTH was presumably secondary to the withdrawal of cortisol production. In contrast, Semple et al $^{(6)}$ reported an apparent fall in bioassayable ACTH levels during angiotensin II infusion in normal man.

Any action of angiotensin II on the pituitary gland, either to stimulate or suppress ACTH, is likely to affect aldosterone production. In man, physiological increases in ACTH are known to stimulate short term ${ }^{7,8)}$ aldosterone secretion. Furthermore, there is evidence from both in vitro and in vivo experiments ${ }^{151,16)}$ that $\mathrm{ACTH}$ potentiates the aldosterone secretion induced by angiotensin II.

Two suggestions may be proposed from the present study of aldosterone levels after dexamethasone administration. First, since baseline levels of PAC were lowered in each subject by dexamethasone administration, ACTH is an important determinant of plasma aldosterone levels. This is supported by the fact that preinfusion levels of PAC were significantly reduced by dexamethasone administration. Second, the observations that plasma cortisol decreased after dexamethasone administration and did not change with angiotensin II administration, and that the aldosterone responses in both the control and dexamethasone-treated conditions were the same, suggest that the adrenal responsiveness to angiotensin II may be a direct effect of the infusion rather than an indirect, ACTH-mediated effect. Thus, the observation that angiotensin II can stimulate ACTH release seems unlikely in normal man.

It may be noteworthy in the present study that the aldosterone response to angiotensin II was significantly enhanced by simultaneous administration of dexamethasone and captopril. On the other hand, it has been well documented that aldosterone responsiveness to angiotensin II is heightened by sodium depletion. ${ }^{9}$ Although the cause of this discrepancy is not clear, one may speculate that the enhanced aldosterone response to angiotensin II is a result of increased adrenal angiotensin II receptor sites. These sites could 
further react with the infused octapeptide, since unoccupied adrenal receptor sites for angiotensin II may increase when endogenous angiotensin II levels decline after treatment. It is also possible that captopril can directly sensitize the adrenal cortex to angiotensin II. In any case, the simultaneous administration of dexamethasone and captopril may be a useful maneuver to assess in more detail the responses of the adrenal cortex to angiotensin II, since the protocol excludes endogenous factors (angiotensin II and/or ACTH) which affect the sensitivity. Therefore, the combined administration of dexamethasone and captopril may offer an opportunity to examine the aldosterone response to exogenous angiotensin II in cases with abnormal pituitary-adrenocortical and/or renin-angiotensin systems.

Our data indicate no differences in blood pressure responses to angiotensin II infusion between the control, dexamethasone-treated, and dexamethasone plus captopril-treated groups. Although the reasons for this discrepancy between the blood pressure and aldosterone responses are unclear, the relatively small infusion doses may be a contributing factor.

Previous data from humans ${ }^{17}$ ) showed that serum potassium levels were raised by long-term treatment of captopril. Further, data from earlier studies indicate that aldosterone secretion can be stimulated by increased potassium concentration. ${ }^{18), 19)}$ A direct effect of serum potassium on aldosterone secretion has been shown in studies in which potassium salts were infused directly into the adrenal artery of sheep with their adrenals transplanted into the neck. ${ }^{18)}$ However, serum potassium levels did not change in the present study. This may indicate that the duration of captopril administration was too short to significantly raise the serum potassium levels. Therefore, scrum potassium does not contribute to the enhanced response of aldosterone with captopril treatment. From these perspectives it is suggested that the aldosterone response to angiotensin II is not dependent upon ACTH secretion, and that simultaneous administration of dexamethasone and captopril may be a useful approach to clarify the adrenal responses to exogenous angiotensin II in man.

\section{REFERENCES}

1. Laragh JH, Angers M, Kelly WG, Lieberman S: The effect of epinephrine, angiotensin II, and others on the secretory rate of aldosterone in man. JAMA 174: 234, 1960

2. Ames RP, Borkowski AJ, Scincinski AM, Laragh JH: Prolonged infusions of angiotensin II and norepinephrine and blood pressure, electrolyte balance, aldosterone and cortisol secretion in normal man and in cirrhosis with ascites. J Clin Invest 44: 1171, 1965

3. Maran JW, Yates FE: Cortisol secretion during intrapituitary infusion of angiotensin II in conscious dogs. Am J Physiol 233: E272, 1975

4. Ramsay DJ, Keil LC, Sharpe MC, Shinsanko J: Angiotensin II infusion increases vasopressin, 
ACTH, and I1-hydroxycorticosteroid secretion. Am J Physiol 234: R66, 1978

5. Rayyis SS, Horton R: Effect of angiotensin II on adrenal and pituitary function in man. $\mathrm{J}$ Clin Invest 32: 539, 1971

6. Semple PF, Buckingham JC, Mason PA, Fraser R: Suppression of plasma ACTH concentration by angiotensin II infusion in normal humans and in a subject with $17 \alpha$-hydroxylase defect. Clin Endocrinol (London) 10: 137, 1979

7. Kem DC, Gomez-Sanchez C, Kramer NJ, Holland OB, Higgins JR: Plasma aldosterone and renin activity response to $\mathrm{ACTH}$ infusion in dexamethasone suppressed normal and sodiumdepleted man. J Clin Endocrinol Metab 40: 116, 1975

8. Mason PA, Lebel M, Frascr R: A comparison of the dose-response relationships between ACTH and the corticosteroids, cortisol, 11 deoxycortisol, corticosterone, 11 deoxycorticosterone, 18 hydroxy DOC and aldosterone in normal human subjects. Acta Endocrinol (Suppl 1) $80: 364,1975$

9. Oelkers W, Brown JJ, Fraser R, Lever AF, Morton JJ, Robertson JIS: Sensitization of the adrenal cortex to angiotensin II in sodium-depleted man. Circulat Res 34: 69, 1974

10. Hollenberg NK, Chenitz WR, Adams DF, Williams GH: Reciprocal influence of salt intake on adrenal glomerulosa and renal vascular response to angiotensin II in normal man. J Clin Invest 54: 34, 1974

11. Fukuchi S, Katsushima I, Takeuchi T: Measurement of plasma aldosterone by radioimmunoassay. Clin Endocrinol (Tokyo) 19: 945, 1971 (in Japanese)

12. Fukuchi $\mathrm{S}$, Nakajima K, Haruyama K: Measurement of plasma cortisol by radioimmunoassay. Clin Endocrinol (Tokyo) 24: 339, 1976 (in Japanese)

13. Fukuchi $\mathrm{S}$, Katsushima I: Measurement of plasma angiotensin II by radioimmunoassay. Tohoku J Exp Med 163: 163, 1971

14. Mizuno K, Hata S, Fukuchi S: Effect of sodium intake on angiotensin-converting enzyme activity of aorta in rats. Clin Sci $61: 249,1981$

15. Kaplan NM, Cook R: The biosynthesis of adrenal steroid. Effect of angiotensin II, adrenocorticotropin, and potassium. J Clin Invest 44: 2029, 1965

16. Kinson GA, Singer B: Sensitivity to angiotensin and adrenocorticotrophic hormone in sodium deficient rat. Endocrinology 83: 1108, 1968

17. Lijnen P, Fagard R, Staessen J, Verschueren LJ, Amery A: Dose response in captopril therapy of hypertension. Clin Pharmacol Ther 28: 310, 1980

18. Blair-West JR, Coghlan JP, Denton DA, Golging JR, Wintour M, Wright RD: The control of aldosterone secretion. Recent Prog Hormone Res 19: 311, 1963

19. Davis JO, Urquhart J, Higgins JT Jr; The effects of alterations of plasma potassium concentration on aldosterone secretion. J Clin Invest 42: 597, 1963 